\title{
DECOLOURISATION OF PALM OIL MILL EFFLUENT (POME) TREATMENT TECHNOLOGIES: A REVIEW
}

\author{
SYAHIN, M S*; W A WAN AB KARIM GHANI* and LOH, S K**
}

\begin{abstract}
Since last decade, global demand for edible oil is growing resulting in a remarkable increase in the areas under oil crop cultivation. The Malaysian palm oil industry is one of the largest palm oil producers in the world. In processing palm oil, high volume of liquid waste known as palm oil mill effluent (POME) is generated. The increasing demands of crude palm oil has resulted in the enormous increase of the number of palm oil mills in Malaysia contributing to large amount of POME. Currently, treatment technologies of POME gain a lot of attention in order to meet the standard discharge limits. The colour of POME, which previously was not an issue, is recently being highlighted and it will be incorporated in the regulation soon. Thus, this article provides review on colourants in POME and its possible decolourisation treatments. The possible decolourisation technologies that will be highlighted in this article are adsorption, coagulation and flocculation, membrane technology, microbial treatment, photocatalysis, etc. including their potential in POME colour removal efficiency.
\end{abstract}

Keywords: palm oil, environmental regulation, wastewater treatment, colour removal.

Date received: 9 April 2018; Sent for revision: 16 May 2018; Accepted: 1 May 2019.

\section{INTRODUCTION}

Palm oil industry is the largest agricultural sector in Malaysia that contributes to the country economic prosperity. It has become the world's second largest - behind Indonesia - producer and exporter of palm oil and its products. Malaysia has tropical climate suitable for oil palm cultivation. In fact, the crude palm oil (CPO) production has risen from 1.3 million tonnes in 1975 to approximately 20 million tonnes in 2018 compared to 19.5 million tonnes in the previous year (MPOB, 2015; Ying, 2018). It was reported that the number of palm oil mills has increased massively from about 10 mills in 1960 to 451

\footnotetext{
Department of Chemical and Environmental

Engineering/Sustainable Process Engineering

Research Centre (SPERC),

Faculty of Engineering,

Universiti Putra Malaysia,

43400 UPM Serdang, Selangor, Malaysia.

E-mail:wanazlina@upm.edu.my

** Malaysian Palm Oil Board,

6 Persiaran Institusi, Bandar Baru Bangi,

43000 Kajang, Selangor, Malaysia.
}

operated mills in 2018 in order to meet the CPO demands both locally and internationally (MPOB, 2018). The wet palm oil milling process is a typical way to extract palm oil from fresh fruit bunches (FFB) which consumes large amount of water and steam. During the extraction process, about $1.5 \mathrm{~m}^{3}$ water per tonne FFB processed is required and half of that becomes palm oil mill effluent (POME) (Loh et al., 2013). Even though the economy grows enormously in this industry, it also generates large amounts of waste in the form of POME (60\%), empty fruit bunch (EFB) $(23 \%)$, mesocarp fibre $(12 \%)$ and palm kernel shell (PKS) (5\%) for every tonne of FFB in the milling process (Azhari et al., 2010; Loh, 2017). The disposal of large quantity of waste generated by the palm oil industry is a challenging task and often seen as a serious environmental issue.

POME is a highly polluting wastewater (Ahmad and Chan, 2009) and has characteristics of thick brownish viscous liquid with a distinct offensive colour and an unpleasant odour, high colloidal suspension and slurry. As the production of $\mathrm{CPO}$ increases, so does the quantity of POME, e.g. in 2008, 44 million tonnes of POME were generated and it has increased to about 64 million tonnes in 2014 
(Loh et al., 2014). The value is expected to increase as the CPO production increase by year. POME is one of the most difficult wastes to be managed due to its large volumes generated at a time (Madaki and Seng, 2013). POME is generated from the sterilisation, hydrocyclone clarification and shell/ kernel separation in the line of CPO production with steriliser condensate and separator sludge being the two major sources of POME contributing the high strength characteristic (Poh et al., 2010). However, as no chemicals are added in the CPO extraction, the POME generated is non-toxic to the environment (Ma et al., 1993).

Current conventional POME treatment method and emerging technologies have been given attention as evidenced by the large number of researches and reviews which have been published in order to find approachable solutions for managing POME. This article aims to review concisely and report on decolourisation treatment technologies of POME as to gain an insight for better POME management.

\section{PROCESS DESCRIPTION AND SOURCES OF POME}

The wet palm oil milling process is typically a method that has been applied in most mills throughout Malaysia. Normally, steam and water are used to leach out the oil which contributes to huge consumption of water resources and also generation of wastewater in the palm oil mills. Figure 1 illustrates the stages involved in $\mathrm{CPO}$ extraction and POME generation. The following

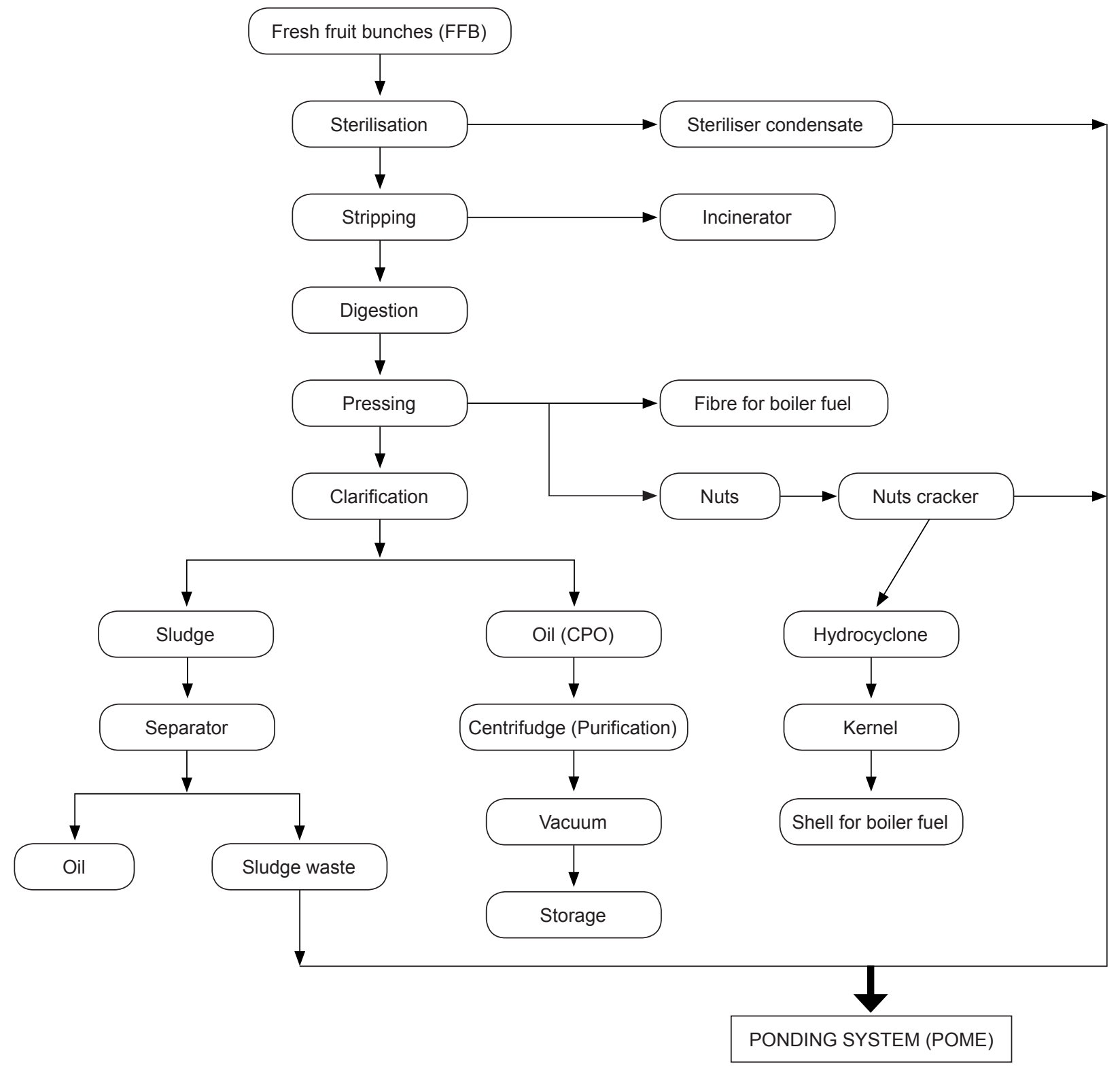

Figure 1. Flow diagram of crude palm oil (CPO) extraction and palm oil mill effluent (POME) generation. 
section summarises some primary palm oil milling processes and sources of POME (Hassan et al., 2006; Liew et al., 2015; Rupani et al., 2010; Wu et al., 2010).

\section{Sterilisation}

The initial stage in extraction of $\mathrm{CPO}$ is sterilisation. Generally, sterilisation is a term referring to a process that eliminates all forms of microbial life (Block, 2001). During sterilisation, steam is injected directly to heat the FFB and to remove air as well. The purpose of this process is to remove external impurities, softening and loosening the fruits from FFB, detaching the kernels from the shells and deactivating the enzymes which are responsible for the build-up of free fatty acids by using hot water and pressurised steam. The presence of free acids in CPO is a concern because it leads to low production of oil since fat-splitting enzymes would hydrolyse much of the oil during the fruit pulping process. Buildup of free fatty acids during the process needs to be alerted so that maximum and good quality $\mathrm{CPO}$ can be produced. Steriliser condensate resulted from the steam consumption as shown in Figure 1 is discharged to ponding system. It is about $36 \%$ of this stage contributes to POME (Poh and Chong, 2009). Increasing level of this condensate affects the quality of the fruits and the oil will be washed out from the bunches in large quantities. Approximately $0.9 \mathrm{t}$ of condensate is generated for every tonne CPO processed (Wu et al., 2010).

\section{Stripping or Threshing}

Upon completion of the sterilisation, the sterilised fruits are stripped and separated from the bunch stalk in a rotary drum thresher. At this stage, the fruits are elevated and dropped through the thresher in order to be knocked out of bunches.
The loose fruits are then transferred to the next process while the EFB can be recycled to the plantation as organic fertiliser or for mulching.

\section{Digestion and Pressing}

The loose fruits undergo digestion process in a heated cylindrical vessel equipped with stirrer and expeller arms. Mainly, this process digests and presses the fruits to loosen the mesocarp from the nuts. Hot water and steam are used to ease the oil extraction from the digested mesocarp. After that, the homogenous oil mash from the digester is moved forward through a screw press. The extracted oil is then purified and clarified in the next stage.

\section{Oil Extraction, Clarification and Purification}

Large amount of water is required during oil extraction process which is generally obtained from the freshwater resources, i.e. river. Homogenous oil mash is produced during the digestion process and is passed through a screw press followed by a hydrocyclone to remove water and fine solids. CPO is produced after the extracted oil is clarified and purified. Centrifuge and vacuum dryer are used to purify the oil before transferring it to a storage tank. At the same time, dirt and other impurities are removed from the oil. The CPO is subjected to high temperature in order to decrease its moisture content before sending to a storage tank. This step is essential to control the rate of oil deterioration during storage before its processing at a palm oil refinery. The by-product of clarification and purification process, i.e. the sludge, is the main source of POME in terms of pollution strength and quantity. About $1.5 \mathrm{t}$ of sludge waste are generated per tonne of CPO produced. The properties of the sludge are shown in Table 1. Sludge from the separator is much more than in the other waste

TABLE 1. CHARACTERISTICS OF DIFFERENT SOURCES OF WASTEWATER FROM CRUDE PALM OIL PRODUCTION*

\begin{tabular}{|c|c|c|c|}
\hline Parameters $^{\mathrm{a}}$ & Steriliser condensate & Clarification wastewater & Hydrocylone wastewater \\
\hline $\mathrm{pH}$ & 5.0 & 4.5 & - \\
\hline Oil and grease & 4000 & 7000 & 300 \\
\hline Biochemical oxygen demand $(\mathrm{BOD})_{3}{ }^{\mathrm{b}}$ & 23000 & 29000 & 5000 \\
\hline Chemical oxygen demand (COD) & 47000 & 64000 & 15000 \\
\hline Suspended solids & 5000 & 23000 & 7000 \\
\hline Dissolved solids & 34000 & 22000 & 100 \\
\hline Total nitrogen & 600 & 1200 & 100 \\
\hline Ammoniacal-nitrogen & 20 & 40 & - \\
\hline Percentage composition $(\%)$ & 36 & 60 & 4 \\
\hline
\end{tabular}

Note: a All parameters are in units of $\mathrm{mg}$ litre ${ }^{-1}$ except $\mathrm{pH}$.

b The sample for $\mathrm{BOD}$ analysis is incubated at $30^{\circ} \mathrm{C}$ for three days.

Source: *Liew et al. (2015). 
streams which is the result of a higher proportion of carbohydrate constituents, both soluble and insoluble (Ho et al., 1984). This could be the reason why biochemical oxygen demand (BOD) is very high in this waste stream.

\section{Nut Cracking}

During the pressing process to extract the oil, pressed cake comprising nuts and fibres are produced. Before being transferred to the nut/ fibre separator, the pressed cake undergoes a preliminary breaking treatment to separate nuts and fibres by use of an air stream or by mechanical means. After that, the nuts are polished in order to remove any remaining fibres before passing to the nut cracking machine. The cracked mixture of shells and kernels is then separated based on their differences in specific gravity using upward suction (hydrocyclone) and a clay bath in a winnowing column. Any uncracked nuts must be removed and recycled. The washing water of the hydrocyclone is the third source of POME at approximately $0.1 \mathrm{t} \mathrm{t}^{-1}$ of CPO produced. It makes up around $4 \%$ of the POME. The properties of the hydrocyclone wastewater are shown in Table 1.

The main waste streams include steriliser condensate, clarification wastewater and hydrocyclone wastewater constitute the POME are presented in Table 1. The quantities of these main streams rely on the palm oil mill operation since its volume is unpredictable. Clarification wastewater contributes to about $60 \%$ of POME as compared to others due to large amount of water used during the oil extraction. The used water is then further delivered in a waste stream to the ponding system.

\section{CHARACTERISTIC OF POME}

\section{Important Characteristic of POME}

POME is generated mainly from the combination of separator sludge, hydrocyclone wastewater and steriliser condensate. Table 1 shows that the separator sludge contains higher level of solid residues than the steriliser condensate and hydrocyclone wastewater. On average, $3.05 \mathrm{t}$ of POME per tonne of CPO production is generated in the extraction process (Subramaniam et al., 2008). Upon discharge from the mill, POME is a thick brownish colloidal mixture of water, oil and fine suspended solids (Wu et al., 2010). The suspended solids in POME consist of oil residues, short palm fibre, cell walls, organelles, variety of carbohydrates ranging from cellulose to simple sugars, a range of nitrogenous compounds from proteins to amino acids, free organic acids and assembly of minor organic and mineral constituents (Ugoji, 1997). Currently, ponding system is the most common treatment method for POME due to low operating and capital costs. However, this common method is becoming more unattractive due to the release of methane to the environment (Wu et al., 2010).

POME contains residual oil that cannot be easily separated by conventional gravity-based systems. This has resulted in a high BOD of POME which is 100 times as polluting as domestic sewage. Thus, POME cannot be discharged without first being treated. BOD is normally used as an indication of the organic quality or the degree of organic pollution of water (Madaki and Seng, 2013). POME is also low in $\mathrm{pH}$, which is about 4.5 due to the organic acids produced during the anaerobic digestion. As it contains organic acids in complex form, it is suitable to be used as carbon sources for microbial manipulation (Alias and Tan, 2005). The temperature of raw POME is approximately $80^{\circ} \mathrm{C}-90^{\circ} \mathrm{C}$ due to the introduction of heat and vigorous mechanical processes during palm oil milling (Hassan et al., 2006). POME is non-toxic since no chemicals are added to the extraction process (Khalid and Wan Mustafa, 1992).

Generally, the characteristic of POME varies widely and is dependent on the operation and quality control of individual mills; and also, activities such as closure of the mill and occasional public holidays (Hassan et al., 2006; Yacob et al., 2006). It also varies considerably for different batches, days and factories, relying on the processing techniques and the age or type of fruits (Ng et al., 1987). Table 2 showed the permissible limits of critical parameters for industrial effluent according to Environmental Quality (Industrial Effluents) Regulation 2009. The regulation specifies two standards for effluent discharge which are Standard A and Standard B. Standard A is for discharges into any inland waters within catchment area whereas Standard B is for discharges into any other inland water throughout Malaysia (DOE, 2010). Particulates which consist of plant cell debris and fragments are completely organic in nature as shown by the very low ash content (Ho et al., 1984). Besides organic composition, POME is also rich in mineral content, particularly phosphorus $(180 \mathrm{mg}$ litre $\left.^{-1}\right)$, potassium (2270 mg litre $\left.{ }^{-1}\right)$, magnesium (615 mg litre $\left.{ }^{-1}\right)$ and calcium (440 mg litre $\left.{ }^{-1}\right)$ (Hassan et al., 2006; Badroldin, 2010). These minerals are vital nutrient elements for plant growth (Habib et al., 1997).

\section{Conventional Treatment of POME}

Common method for treating POME is the open pond system which employs the open type lagoon treatment. Approximately 85\% of POME treatment 
TABLE 2. PARAMETERS LIMIT FOR INDUSTRIAL EFFLUENT*

\begin{tabular}{|c|c|c|c|}
\hline \multirow{2}{*}{ Parameters } & \multirow{2}{*}{ Unit } & \multicolumn{2}{|c|}{ Standard } \\
\hline & & $\mathbf{A}$ & B \\
\hline Biochemical oxygen demand $\left(\mathrm{BOD}_{5}\right)^{\mathrm{a}}$ & mg litre ${ }^{-1}$ & 20 & 40 \\
\hline Chemical oxygen demand (COD) & mg litre ${ }^{-1}$ & 80 & 200 \\
\hline Suspended solids & mg litre ${ }^{-1}$ & 50 & 100 \\
\hline Oil and grease & mg litre ${ }^{-1}$ & 1.0 & 10 \\
\hline Ammoniacal-nitrogen & mg litre ${ }^{-1}$ & 10 & 20 \\
\hline $\mathrm{pH}$ & - & $6.0-9.0$ & $5.5-9.0$ \\
\hline Temperature & ${ }^{\circ} \mathrm{C}$ & 40 & 40 \\
\hline Colour & $\mathrm{ADMI}^{\mathrm{b}}$ & 100 & 200 \\
\hline
\end{tabular}

Note: a The sample for BOD analysis is incubated at $20^{\circ} \mathrm{C}$ for five days.

${ }^{\mathrm{b}}$ American Dye Manufacturers Institute.

Source: *DOE (2010).

TABLE 3. SUMMARY OF PONDING SYSTEM

\begin{tabular}{|c|c|c|c|}
\hline Process & Function & Advantages & Limitation \\
\hline Cooling & Cool down the POME to lower than $35^{\circ} \mathrm{C}$ & Low HRT & Has the strongest sourly smell \\
\hline Acidification & $\begin{array}{l}\text { Convert the organic components into } \\
\text { volatile fatty acids (VFA) and depresses } \\
\text { the } \mathrm{pH} \text { of the system }\end{array}$ & $\begin{array}{l}\text { Promote the growth of the acid } \\
\text { formers. Short HRT }\end{array}$ & $\begin{array}{l}\text { The contents are thick and a } \\
\text { layer of solid is covering the } \\
\text { top }\end{array}$ \\
\hline Anaerobic & $\begin{array}{l}\text { Digest high organic contents and generates } \\
\text { biogas }\end{array}$ & $\begin{array}{l}\text { Low capital investment and } \\
\text { operational energy }\end{array}$ & $\begin{array}{l}\text { Longer HRT. Extensive land } \\
\text { area }\end{array}$ \\
\hline Facultative & $\begin{array}{l}\text { Allow heavy solids settle down at the } \\
\text { bottom and lighter solids float at the } \\
\text { surface }\end{array}$ & $\begin{array}{l}\text { Stabilisation pond. Reliable } \\
\text { process. Easy to operate }\end{array}$ & $\begin{array}{l}\text { Lack of sludge removal } \\
\text { capability. Land intensive }\end{array}$ \\
\hline Aerobic & $\begin{array}{l}\text { Decompose organic matter by bacteria in } \\
\text { the presence of oxygen }\end{array}$ & $\begin{array}{l}\text { More efficient and short HRT } \\
\text { compared to anaerobic } \\
\text { process }\end{array}$ & High operating cost \\
\hline
\end{tabular}

Note: POME - palm oil mill effluent; HRT - hydraulic retention time.

is based on conventional biological treatment methods of acidification, anaerobic, facultative and aerobic degradation (Loh et al., 2013). Normally, ponding system includes sand and oil trap, cooling ponds, acidification ponds, anaerobic ponds, facultative ponds, and aerobic ponds (Liew et al., 2015). According to Loh et al. (2013), the current ponding system in Kilang Kelapa Sawit Labu, Sime Darby in Negeri Sembilan, Malaysia, consists of a cooling pond, an acidification pond, two anaerobic ponds, two facultative ponds, and a final discharge pond. The overall hydraulic retention time (HRT) of this ponding system is more than 100 days based on the current processing capacity of the mill.

Acidification pond is a stage to promote the growth of acid producing bacteria and its associated enzymes in order to degrade organic material into fatty acids. This stage is a very rapid process with its HRT of only two days. Meanwhile, anaerobic pond allows high organic contents to be digested by bacteria in the absence of oxygen (Liew et al., 2015). It is characterised by long residence time which is more than 20 days. Facultative pond generally consists of a mix of anaerobic, aerobic and facultative bacteria, which can grow with or without oxygen. It is classified as primary clarifier of conventional biological treatment which allows heavy solids to settle down at the bottom and lighter solids float at the surface. Further treatment of POME consists of feeding it into aerobic pond where organic matters are decomposed into carbon dioxide, water and cell biomass by aerobic bacteria in the presence of oxygen. This treatment is more efficient and the HRT is shorter than that for anaerobic digestion. All these ponding systems are summarised in Table 3.

Even though the ponding system is a simple technology, low operating cost and easy to maintain, huge land area and long HRT are required. Besides, it showed relatively poor efficiency with a discharge 
end having high residual chemical oxygen demand (COD) and BOD in the POME (Zhang et al., 2008). Therefore, proper POME treatment is important not only to ensure a sustainable economic growth in the palm oil industry but also to protect the environment.

\section{Colour Resistance}

POME is a potential environmental pollutant requiring urgent attention due to its considerably 'stubborn' colour characteristic. It is seen as a brownish liquid waste and has high turbidity (Ahmad et al., 2006). The discharge of coloured treated POME into a river, though less toxic, is often objected by the public on the visible colour appearance as a sign of pollution (Zahrim et al., 2009). Although the conventional ponding system is upgraded with anaerobic system, anaerobically treated effluent (AnPOME) still consists of dark brown colour (Zahrim et al., 2014). Reuse of AnPOME is one of the alternatives to reduce the impact to the environment, but its dark colour makes the AnPOME unattractive for reuse application (Ratpukdi, 2012). The effluent still remains as a clear brownish solution even after the tertiary treatment (Poh et al., 2010).

The colour of the effluent is due to plant constituents such as lignin, tannin, humic and fulvic acid-like substances and phenolic compounds as well as repolymerisation of colouring compounds including anaerobic fermentation by-product, e.g melanoidin (Zahrim et al., 2014; 2009). The lignin content in POME is around 1700-7890 mg litre $^{-1}$ contributing to brownish colour of the POME (Poh et al., 2010). It also contains $p$-hydroxy-phenyl, syringyland guaiacylunits (Mohan and Karthikeyan, 1997). The POME colour is hard to remove because the lignin and its degraded products are chemically stable, resistant to biological degradation and are intractable to be separated by conventional method (Mohan and Karthikeyan, 1997). It is resistant to biological degradation because of the ligneous structures within an organic complex which have a tendency to shield the cellulose from enzymatic hydrolysis (Han et al., 1975). Moreover, several phenolic compounds in POME are coloured consisting of gallic, protocatechuic, 4-hydroxybenzoic, 4-hydroxylphenylacetic, caffeic, syringic acids, $p$-coumaric and ferulic acids (Jamal et al., 2011). Another factor contributing to colour in the POME is the suspended and dissolved particles in water. Dissolved particles comprise of dissolved organic matters such as humus, peat, or decaying plant matters which can produce a yellow or brown colour (Mohammed and Chong, 2014).

Discharging coloured effluent to water bodies imparts adverse effect on aquatic environment. It inhibits the growth of the desirable aquatic biota necessary for self-purification (re-oxygenation) by filtering the penetration of sunlight, thus, resulting in less photosynthesis activity (Zahrim et al., 2009). It also causes serious depletion of dissolved oxygen which endangers aquatic life as an important source of food and nutrients (Igwe et al., 2010). Therefore, disposing highly coloured POME into a water body could not sustain aquatic life leading to the longterm impairment of the ecosystem.

\section{Decolourisation Treatment of POME}

Decolourisation treatments of POME gain a lot of attention since the colour of POME is very hard to be removed. Several technologies have been introduced providing new ideas and costeffective solution to ensure sustainable palm oil mills operation. The summary of decolourisation technologies is presented in Table 4.

\section{Physico-chemical Treatment}

Physico-chemical POME treatment has received some attention due to the effectiveness and system applicability. It is useful in applications where it is desired to combine an effluent treatment with the recovery of solids. The suggested physico-chemical treatment processes for POME include adsorption and coagulation or flocculation.

\section{Adsorption}

Adsorption is considered to be one of the most effective and proven technologies having potential application in both water and wastewater treatment. It is a rapid process where a molecule collides with a surface and sticks (Masel, 1996). Adsorption performance depends on contact time, dosage of adsorbent, initial concentration and $\mathrm{pH}$ of POME. Mohammed (2013) carried out a comparative adsorption study among palm oil wastes, i.e. PKS and EFB on POME colour. The percentage of colour removal was almost $100 \%$ in $12 \mathrm{hr}$ by activated PKS and EFB. Both PKS and EFB were activated by microwave and chemical. Similar study was carried out by Jalani et al. (2016) using PKS as adsorbent to remove POME colour. The difference was PKS was activated by steam and the maximum colour removal was $76 \%$ within $72 \mathrm{hr}$. Another study by Sia et al. (2017) also performed adsorption method to remove colour from POME using acid washed-coconut shell activated carbon. It was successfully used to remove the colour with percentage removal of $61 \%$ within $48 \mathrm{hr}$. Even though these adsorbents were effective in POME colour removal, the activation process was quite complicated and costly. 


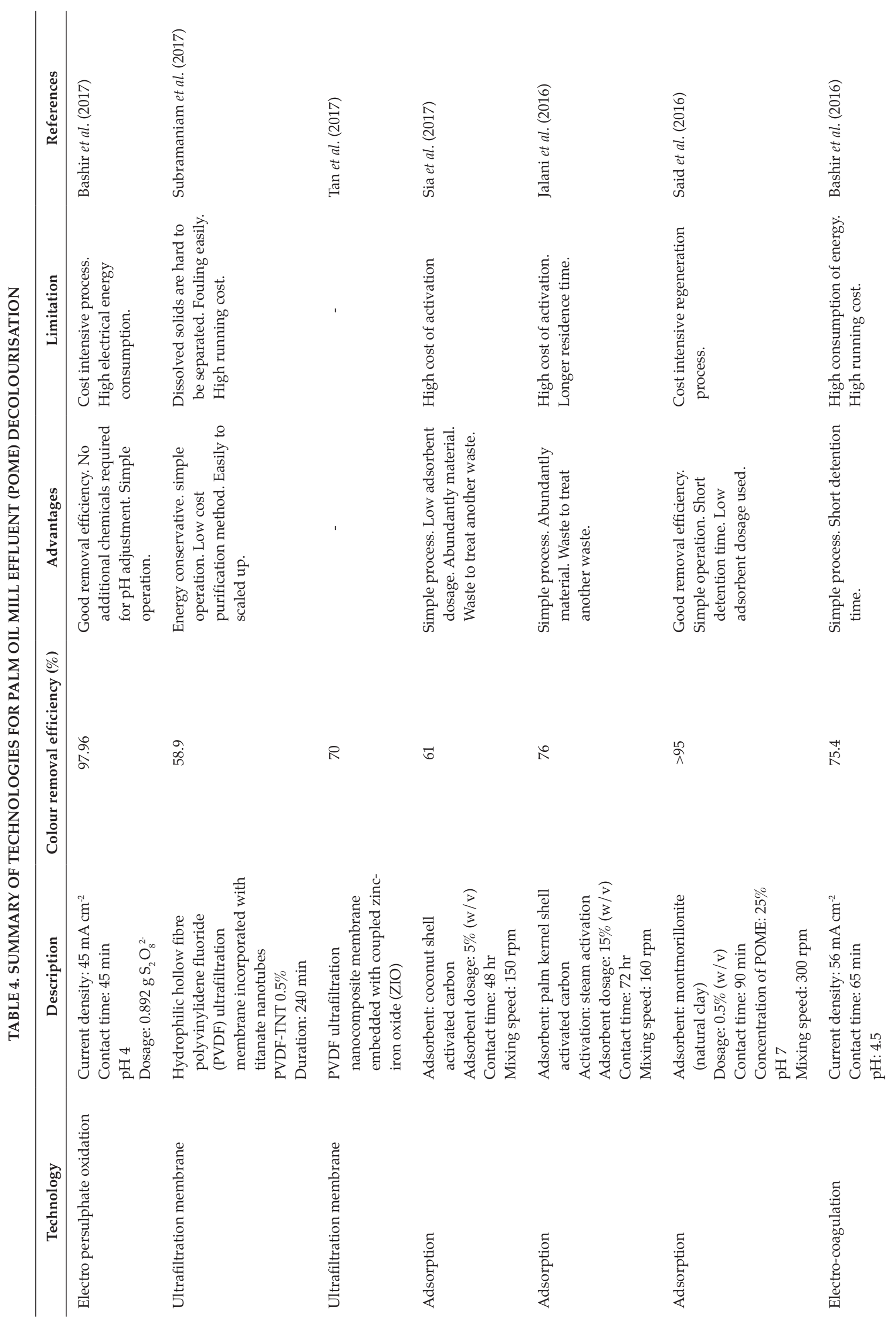




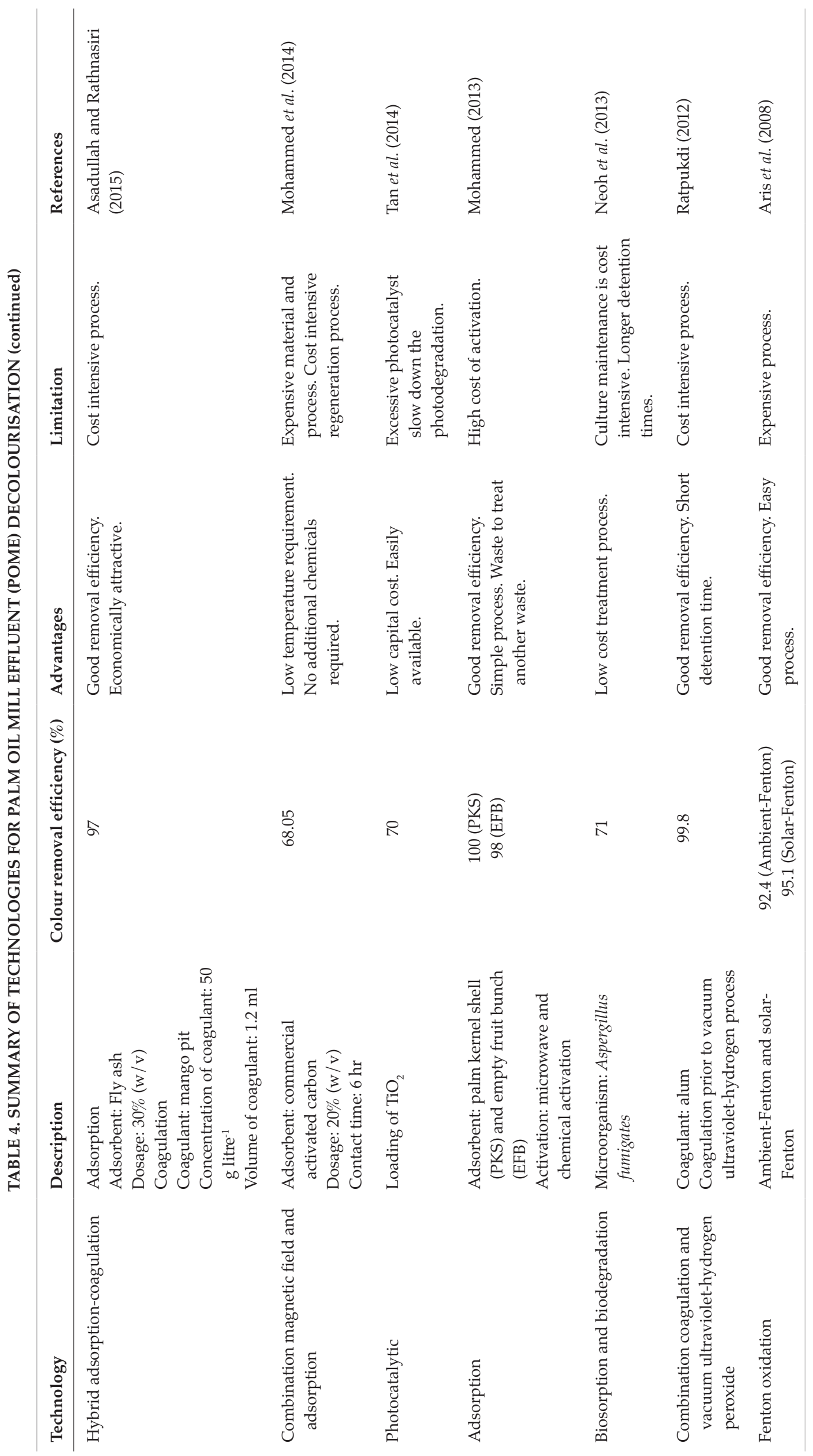


A study by Said et al. (2016) showed that natural clay (montmorillonite) was able to remove POME colour by more than $95 \%$ within $90 \mathrm{~min}$ with $5 \mathrm{~g}$ litre $^{-1}$ in initial concentration of POME of $25 \%$. This study showed that the removal efficiency of montmorillonite for colour was due to the adsorption capacity and surface charge of montmorillonite. The montmorillonite was negatively charged that came from isomorphic substitution and neutralised the cations in the solution which finally deposited on adsorbent surface.

According to Igwe et al. (2010), boiler fly ash had potential in colour removal of POME. The adsorption isotherm of POME showed that Freundlich isotherm gave a better fit followed by Langmuir and then Dubinin-Radushkevich isotherm. This showed that the adsorption took place on a heterogeneous surface, rather than the homogenous surface (Mohammed, 2013). Similar result was obtained by Sia et al. (2017) who revealed that the POME colour adsorption mechanism was mainly due to heterogenous system and chemical sorption. The adsorption rate was affected more by the number of available adsorption sites on the adsorbent surface than the effect of POME solution concentration. Besides, study by Igwe et al (2010) showed that the amount of colour adsorbed increased with the increasing dosage of the boiler fly ash. The increase of percentage of colour removal was due to the increased availability of surface area for adsorption (Mohammed and Chong, 2014). Similarly, smaller particle size of $425 \mu \mathrm{m}$ adsorbed more compared to bigger particle size of $850 \mu \mathrm{m}$ as larger contact area was achieved (Igwe et al., 2010).

The $\mathrm{pH}$ is one of the important parameters for adsorption technology and it has a significant effect on colour removal. It is concerned with the surface charge and degree of ionisation (Said et al., 2017). It was revealed by studies that the colour reduction from POME with high percentage removal mostly was in acidic condition (Jalani et al., 2016; Asadullah and Rathnasiri, 2015; Mohammed, 2013). In acidic condition, more protons will be available to protonate the adsorbent surface thus, increase the electrostatic attraction between negatively charge anion compounds and positively charged adsorption sites, facilitating an increase in the colour reduction (Latif et al., 2014). Study by Bello et al. (2013) stated that coloured organic compounds extracted from POME easily formed negatively charged ion in aqueous due to its structure contain functional group of an aromatic ring, carboxyl group, hydroxyl substituent ranging from simple phenolic molecules to highly polymerised compound. This could be the reason why the colour reduction was mostly performed in acidic condition because there was electrostatic attraction between the negatively charged coloured compounds and positively charged adsorption sites.

A combined magnetic field and activated carbon adsorption process for colour, total suspended solids (TSS) and COD removal of POME treatment (Mohammed et al., 2014) showed a better removal rate in the presence of magnetic effect. The exposure of activated carbon to a magnetic field could influence its magnetically sensitive particles compared to sorbate molecules, thus, enhancing the adsorption performance (Mohammed et al., 2014). The use of magnetic field improved the orientation of the molecules of the adsorbate towards the activated carbon pores, hence, facilitating the adsorptive process, and resulting in a gain in the adsorption time (Brito et al., 2012).

\section{Coagulation and Flocculation}

For many years, coagulation of coloured effluent has been used either as main or pretreatment due to its low capital cost. It is classified into two main categories, i.e. metal coagulant and polymer (Yaser et al., 2013). Coagulation destabilises the suspension and encourages the particles to flocculate and form larger aggregates $(\mathrm{Wu}$ et al., 2010). Meanwhile, flocculation encourages the get together of the destabilised particles, where they stick and form larger aggregates (Bratby, 2006). According to Zahrim et al. (2014), lignin-tannin removal is enhanced by a polymer coagulant, i.e. calcium lactate-cationic polyacrylamide. Addition of polymer in coagulation and flocculation processes in a desired dosage improves the size of the destabilised flocs and consequently enhances the settling rate (Zahrim et al., 2010). Synthetic non-ionic and cationic polymers are excellent in removal of lignin via coagulation and flocculation processes. These, together with natural polymers (chitosan) and chemical coagulant (alum), were found to exhibit different colour removal ability in the order of non-ionic polymer $<$ cationic polymer $<$ alum chemical coagulant $<$ chitosan (Ganjidoust et al., 1997).

A combined chemical coagulation and vacuum ultraviolet (UV)-hydrogen peroxide pre-treatment plays a significant role in the reduction of colour of POME (Ratpukdi, 2012). The resulting colour removal was up to $99.8 \%$ making POME almost colourless. Alum was used prior to vacuum UVhydrogen peroxide process since alum encouraged the particles to flocculate and form aggregates leading to colour reduction. According to Kito et al. (1998), both UV and hydrogen peroxide can be used alone to facilitate the degradation of certain contaminants since hydrogen peroxide is capable of destroying some halogenated compounds and most non-halogenated compounds in aqueous solution 
whereas UV light itself is capable in degradation of contaminants by initiating bond cleavage. Yet, there is a limitation on the range of contaminants UV can degrade; thus, the time for the degradation is slow. Besides, any hindrance of the UV transmission light to the sample can decrease the efficiency of the process. This makes operation cost higher as optimisation is required. Hence, the combined hydrogen peroxide and UV treatment may be an efficient process for bio remediation.

Currently, electro-coagulation has been focused on by researchers to upgrade coagulation and flocculation technology. Study by Bashir et al. (2016) showed that using electro-coagulation method is able to decolourise POME up to $75.4 \%$ after 65 min contact time by using current density of 56 $\mathrm{mA} \mathrm{cm} \mathrm{cm}^{-2}$ at $\mathrm{pH}$ 4.5. This method proved that the reduction of POME colour takes a shorter time as compared to coagulation method and it is a simple method as well. However, this technology is high cost due to requirement of high energy to operate. Hybrid technology also had been applied in order to upgrade the current technology and improve the reduction of colour from POME as well such as combination of adsorption-coagulation method. Hybrid adsorption-coagulation method using natural coagulant, i.e. mango pit and palm oil boiler fly ash (POBFA) as adsorbent was studied by Asadullah and Rathnasiri (2015) in order to remove the colour and other impurities present in POME. It was reported that the percentage removal of colour from POME was $97 \%$. A few advantages have been highlighted using this hybrid process which are cost-effective, environmental-friendly process and improving water quality.

\section{Membrane Technology}

Membrane technology was reported to be able to produce reusable water by recovering the colour of effluent. This method has the ability to concentrate, clarify and separate colour continuously from the effluent (Anjaneyulu et al., 2005). For decolourisation, this technology is used to separate and remove colour pigments via molecular sieving mechanism (Nataraj et al., 2009). Subramaniam et al. (2017) applied polyvinylidene fluoride (PVDF) nanocomposite ultrafiltration (UF) with hollow fibre membrane incorporated with titanate nanotubes (TNT) for decolourisation of aerobicallytreated palm oil mill effluent (AT-POME). The novelty of UF membrane was fabricated by dry / wet phase inversion technique. TNT offered superior surface area and hydrophilicity. The enhancement of membrane hydrophilicity promoted and improved membrane water permeation. The UF membrane exhibited the most promising result with colour removal of $58.9 \%$ with $0.5 \%$ TNT throughout a period of $240 \mathrm{~min}$. Furthermore, this membrane showed very minimal signs of fouling and able to operate until five continuous cycles. Similar study was carried out by Tan et al. (2017) who applied the same type of UF membrane but the incorporation of metal oxide was different. In this study, PVDF UF membrane incorporated with coupled zinc-iron oxide (ZIO) nanoparticles and was fabricated via similar phase inversion process. It was found that POME colour was best removed by $70 \%$ due to the increase in ZIO loading which had drastically increased the membrane surface negativity resulting in repelling the negatively charged colour pigments that were present in the AT-POME and hence, contributed to greater colour reduction.

Generally, zinc oxide as nanoparticles was used to improve the membrane hydrophilicity resulting in low pressure operation and high permeation for AT-POME (Tan et al., 2017). Membrane porosity and surface area, membrane surface charge and membrane wettability influenced the membrane performance in removal of colour from AT-POME. Even though this technology is a simple process and could conserve energy, it still promotes membrane fouling and requires high instalment cost including the fabrication.

\section{Microbial Treatment}

In microbial processing, microorganisms such as bacteria, fungus, and others are used in treating effluent for COD, BOD, TSS and colour removal. Neoh et al. (2013) studied the decolourisation of POME using cultures of Aspergillus fumigates under response surface methodology. The maximum colour removal of POME was $71 \%$ after five days. It showed that the subsequent increase in biomass increased the adsorption of colour as well as other compounds from POME. The biosorption and biodegradation processes involved was simple and economical since POME itself was used as a carbon source for the anticipated growth of the microbial cells in biosorption of colour (Neoh et al., 2013). However, decolourisation of POME using microorganism is very time-intensive as compared to other treatment technologies such as adsorption, oxidation, coagulation and flocculation, etc.

In a separate study, Solemaninanadegani and Manshad (2014), the isolated bacteria, i.e. Micrococcus sp., Bacillus sp., Pseudomonas sp. and Staphylococcus aureus and fungi i.e. Aspergillus niger, Aspergillus fumigates, Candida sp., Fusarium sp., Mucor sp. and Penicillium sp. showed significant effects on biodegradation treatment of POME. Raw POME, autoclaved and non-autoclaved, were incubated for seven days and the activities of the microorganisms were observed at $12 \mathrm{hr}$ interval. 
The result of POME supernatant showed that the non-autoclaved sample degraded better than that of autoclaved one. This suggested that the indigenous microorganisms found in the POME were more effective than the introduced microorganisms. The colour of POME based on the American Dye Manufacturers Institute (ADMI) decreased with increasing number of treatment days for all the samples inoculated with multi-microorganisms as well as the control sample. There was fluctuation in the metabolites of microorganism system dedicated for biodegradation of POME. However, the result showed stability in final stage. Despite the inconsistency, this treatment showed positive tendency in POME colour reduction.

\section{Others}

The use of titanium oxides $\left(\mathrm{TiO}_{2}\right)$ in photocatalytic process can also remove colour from POME (Tan et al., 2014). Different dosages of $\mathrm{TiO}_{2}$ were used to evaluate the effect of catalyst loading towards the photodegradation efficiency of POME. The result showed that $10 \mathrm{wt} \%$ of $\mathrm{TiO}_{2}$ was able to remove $>70 \%$ of the colour pigment. However, the colour reduction only increased slightly when the catalyst loading increased from $5 \mathrm{wt} \%$ to $10 \mathrm{wt} \%$, probably due to the agglomeration of nanoparticles in the POME suspension and the excessive photocatalyst used causing penetration of UVirradiation difficult and consequently slowed down the photodegradation (Tan et al., 2014). Similar method was reported by Cheng et al.(2017), whoused tungsten oxides photocatalyst under UV-irradiation to remove colour from POME. It was found that the maximum percentage of POME colour removal was $98.28 \%$ at optimum reaction time of $16 \mathrm{hr}$. It was highlighted that the tungsten oxides photocatalyst is suitable for photocatalytic decolourisation of POME but not suitable for photocatalytic degradation. Nevertheless, photocatalytic process is still a major challenge since the mechanism is far more complex considering other factors such as type of catalyst, $\mathrm{pH}$, illumination source and additives (Lekelefac et al., 2015).

Aris et al. (2008) carried out a study on tertiary treatment of POME using Fenton oxidation to remove COD and colour. Two types of Fenton process were evaluated, i.e. ambient-Fenton (inside the laboratory under ambient light) and solarFenton (open space directly under the sunlight). The highest removal of colour under ambient-Fenton treatment was $92.4 \%$ and $95.1 \%$ for solar-Fenton treatment. It was shown that the efficiency of colour removal in POME was affected by ferrous ion and hydrogen peroxide dosages during the treatment, but the reaction may be inhibited after optimum dosages were used due to the scavenging effect of radicals resulting in the formation of $\mathrm{HO}_{2}$ The optimum dosages of both the reagents were strongly dependent on the type and strength of the treated wastewater. It can be observed that when the iron dosage was fixed, increasing the hydrogen peroxide dosage from $902.5 \mathrm{mg}$ litre $^{-1}$ to $1397.5 \mathrm{mg} \mathrm{litre}^{-1}$ increased the colour removal from $70 \%$ to about $78 \%$. Conversely, when the iron dosage increased to 384.7 $\mathrm{mg}$ litre $^{-1}$, increasing the hydrogen peroxide by the same magnitude did not increase the performance but indeed reduced the colour removal from $>90 \%$ to about $78 \%$. It can be concluded that solar-Fenton gave a better colour removal than ambient-Fenton (Aris et al., 2008).

Study on oxidation technology had been upgraded to electro persulphate oxidation which was carried out by Bashir et al. (2017). It was a treatment with the combination effects of electrooxidation, electro-coagulation and electro-floatation (Bashir et al., 2017). This technology is considered as an effective process in organic degradation by using anodic adsorbed oxidants or electrochemically generated oxidants in the bulk solution to carry out direct and indirect oxidation simultaneously (Barrera-Díaz et al., 2014). It was found that the colour of POME was removed by $97.96 \%$ with $45 \mathrm{~mA}$ $\mathrm{cm}^{-2}$ of current density, 45 min of contact time, $\mathrm{pH} 4$ and $0.892 \mathrm{~g} \mathrm{~S}_{2} \mathrm{O}_{8}{ }^{2-}$. The experiment was conducted by using two aluminium plates as anode and cathode. According to the study, the percentage removal of colour increased with current density and contact time. However, the colour removal slowed down after certain time due to very slow mineralisation rate of the remaining organic complexes (Zhu et al., 2014). In this study, electrical energy consumption was the main concern, however, it was found that a smaller amount of energy was consumed as compared to the energy consumed by conventional electro-coagulation process.

\section{FUTURE PROSPECTS}

Wastewater treatment technology is amongst the most vital component in a palm oil mill operation due to the large quantity of POME generated during $\mathrm{CPO}$ production. Although the first stage of the anaerobic treatment of POME is effective in degrading the BOD, it does not have the ability to decolourise the POME. This has led to urgency to further explore R\&D to reach a solution that can offer POME discharge limit compliance.

Basically, almost all types of wastewater treatment technologies established have been attempted in POME decolourisation. Yet, none of the stand-alone treatment could decolourise POME satisfactorily. Currently, integrated system is widely studied by researchers as an alternative to stand- 
alone treatment for better POME decolourisation. Combination of a few potential technologies on POME decolourisation is applicable and practical in the future after considering several factors such as cost effectiveness, operational consistency, and system sustainability if operated as full-scale treatment plants in palm oil mills. Integrated system gains much attention as this kind of approach is the key to ensure the palm oil industry moving towards the goal of environmental sustainability. One of the feasible technologies could possibly be a combined advanced biological process followed by solids separation prior to discharge.

The physical and chemical properties of POME are crucial that need to be considered in order to implement full-scale technologies. Gap between treatability studies and full-scale treatment plants needs to be narrowed down by extensive research. Other issues that need to be considered in POME decolourisation are scalability, operational troubleshooting in full-scale treatment plants, wastewater characterisation and technological researches for better understanding of unit processes, process optimisation and operational flaws identification.

\section{CONCLUSION}

The treated effluent from the anaerobic digestion of POME is always dark brownish due to recalcitrant nature of POME. Coloured POME is influenced by the presence of lignin and tannin substances which unfortunately is not publicly receptive and is always linked to the environmental pollution. Several possible decolourisation treatment methods are adsorption, coagulation and flocculation, biodegradation, biosorption, photodegradation and others. However, none of the stand-alone treatment could fully decolourise POME, and hence, integrated system is required. Coagulation and flocculation show more potential as pre-treatment step followed by adsorption process for colour removal. Other decolourisation treatment technologies are also possible but require more technologies integration dependent on the palm oil mill operation system, capacity of oil mill, the ultimate mode of discharge, the economics of the establishment and maintenance facilities.

\section{ACKNOWLEDGEMENT}

The authors wish to acknowledge the financial support from the Engineering and Physical Sciences Research Council for partial funding of this research through the BEFEW project (Grant No. EP/ P018165/1).

\section{REFERENCES}

Ahmad, A L and Chan, C Y (2009). Sustainability of palm oil industries: An innovative treatment via membrane technology. J. Applied Science, 9: 30743079.

Ahmad, A L; Chong, M F; Bhatia, S and Ismail, S (2006). Drinking water reclamation from palm oil mill effluent (POME) using membrane technology. Desalination, 191: 35-44.

Alias, Z and Tan, I K P (2005). Isolation of palm oilutilising, polyhydroxyalkanoate (PHA)-producing bacteria by an enrichment technique. Bioresource Technology, 96: 1229-1234.

Anjaneyulu, Y; Chary, N S and Raj, D S S (2005). Decolourization of industrial effluents - Available methods and emerging technologies - A review. Reviews in Environmental Science and Bio/Technology, 4: 245-273.

Aris, A; Siew, O B; Kee, K S and Ujang, Z (2008). Tertiary treatment of palm oil mill effluent using fenton oxidation. Malaysian J. Civil Engineering, 20(1): 12-25.

Asadullah and Rathnasiri, P G (2015). Optimization of adsorption-coagulation process for treatment of palm oil mill effluent (POME) using alternative coagulant. International Research Symposium on Engineering Advancements. Sri Lanka. p. 68-71.

Azhari, S B; Lim, S H; Zulkhairi, M; Rahman, N A A; Shah, U K M and Hassan, M A (2010). Effects of palm oil mill effluent (POME) anaerobic sludge from $500 \mathrm{~m}^{3}$ of closed anaerobic methane digested tank on pressed-shredded empty fruit bunch (EFB) composting process. African J. Biotechnology, 9(16): 2427-2436.

Badroldin, N A B (2010). Treatment of Palm Oil Mill Effluent (POME) Using Hybrid Up Flow Anaerobic Sludge Blanket (HUASB) Reactor. Master thesis, Universiti Tun Hussein Onn, Malaysia. 56 pp.

Barrera-Díaz, C; Canizares, P; Fernandez, F J; Natividad, R and Rodrigo, M A (2014). Electrochemical advanced oxidation processes: An overview of the current applications to actual industrial effluents. J. Mexican Chemical Society, 58: 256-275.

Bashir, M J K; Han, T M; Wei, L J; Aun, N C and Amr, SS A (2016). Polishing of treated palm oil mill effluent (POME) from ponding system by electro-coagulation process. Water Science \& Technology, 73(11): 2704-2712. 
Bashir, M J K; Wei, C J; Aun, N C and Abu Amr, S S (2017). Electro persulphate oxidation for polishing of biologically treated palm oil mill effluent (POME). J. Environmental Management, 193: 458-469.

Bello, M M; Nourouzi, M M; Abdullah, L C; Choong, T S Y; Koay, Y S and Keshani, S (2013). POME is treated for removal of color from biologically treated POME in fixed bed column: Applying wavelet neural network (WNN). J. Hazardous Materials, 262: 106-113.

Block, S S (2001). Disinfection. Sterilization and Preservation. $5^{\text {th }}$ Edition, Lippincott Williams \& Wilkins, Philadelphia. 1481 pp.

Bratby, J (2006). Coagulation and Flocculation in Water and Wastewater Treatment. IWA Publishing. 450 pp.

Brito, J F D; Ferreira, L O; Pereira, M C; Silva, J P and Ramalho, T C (2012). Adsorption of aromatic compounds under magnetic field influence. Water, Air E Soil Pollutin, 223: 3545-3551.

Cheng, Y W; Chang, Y S; Ng, K H; Wu, T Y and Cheng, C K (2017). Photocatalytic restoration of liquid effluent from oil palm agro industry in Malaysia using tungsten oxides catalyst. J. Cleaner Production, 162: 205-219.

Department of Environment (DOE) (2010). Environmental Requirements: A Guide for Investors. $11^{\text {th }}$ edition. doe.gov.my/eia/wp-content/ uploads / 2012/03/A-Guide-For-Investors1.pdf, accessed on 1 October 2010. 71 pp.

Ganjidoust, H; Tatsumi, K; Yamagishi, $\mathrm{T}$ and Gholian, R N (1997). Effect of synthetic and natural coagulant on lignin removal from pulp and paper wastewater. Water Science and Technology, 35: 291296.

Habib, M A B; Yusoff, F M; Phang, S M; Ang, K J and Mohamed, S (1997). Nutritional values of chironomid larvae grown in palm oil mill effluent and algal culture. Aquaculture, 158(1-2): 95105.

Han, Y W; Lee, J S and Anderson, A W (1975). Chemical composition and digestibility of rye grass straw. J. Agriculture and Food Chemistry, 23: 928-931.

Hassan, M A; Yacob, S; Shirai, Y and Hung, Y T (2006). Waste treatment in the food processing industry. Treatment of Palm Oil Wastewater (Wang, L K; Hung, Y T; Lo, H H and Yapijakis, C eds.). Taylor \& Francis Group. p. 101-118.
Ho, C C; Tan, Y K and Wang, C W (1984). The distribution of chemical constituents between the soluble and the particulate fractions of palm oil mill effluent and its significance on its utilization/treatment. Agriculture Wastes, 11: 6171.

Igwe, J C; Onyegrado, C O and Abia, A A (2010). Adsorption isotherm studies of BOD, TSS and colour reduction from palm mill effluent (POME) using boiler fly ash. ECLÉTICA química, 35(3): 195-208.

Jalani, N F; Aziz, A A; Wahab, N A; Hassan, W H W and Zainal, N H (2016). Application of palm kernel shell activated carbon for the removal of pollutant and colour in palm oil mill effluent treatment. J. Earth, Environment and Health Sciences, 2(1): 15-20.

Jamal, P; Idris, Z M and Alam, M Z (2011). Effects of physicochemical parameters on the production of phenolic acids from palm oil mill effluent under liquid-state fermentation by Aspergillus niger IBS-103ZA. Food Chemistry, 124(4): 1595-1602.

Khalid, A R and Wan Mustafa, W A (1992). External benefits of environmental regulation: Resource recovery and the utilization of effluents. The Environmentalist, 12: 277-285.

Kito, M; Nguyen, H and Tran, J (1998). Hydrogen Peroxide and UV Treatment. California Polytechnic State University, California. http://www. calpoly.edu / ceenve/enve / jsczechowski / enve 436 / projects / hydro-perox / H2O2-UVTreatment.html

Latif, A; Suhaimi, A A and Romzay, R A (2014). Application of Elaeis guineensis leaves in palm oil mill effluent treatment. Indian J. Science and Technology, 7(3): 254-261.

Lekelefac, C A; Busse, N; Herrenbauer, M and Czermak, P (2015). Photocatalytic based degradation processes of lignin derivatives. International J. Photoenergy, 2015: 1-18.

Liew, W L; Kassim, M A; Muda, K; Loh, S K and Affam, A C (2015). Conventional methods and emerging wastewater polishing technologies for palm oil mill effluent treatment: A review. J. Environmental Management, 149: 222-235.

Loh, S K (2017). The potential of the Malaysian oil palm biomass as a renewable energy source. Energy Convers. Manage., 141: 285-298. 
Loh, S K; Lai, M E; Ngatiman, M; Lim, W S; Choo, Y M; Zhang, Z and Salimon, J (2013). Zero discharge treatment technology of palm oil mill effluent. J. Oil Palm Res. Vol. 25(3): 273-281.

Loh, S K; Nasrin, A B; Nurul Adela, B; Mohamad Azri, S; Muzzammil, N and Daryl Jay, T (2014). Biogas Capture and Utilization from Palm Oil Mill Effluent. MPOB, Bangi. p. 1-38.

Ma, A N; Cheah, S C and Chow, M C (1993). Current status of palm oil processing wastes management. Waste Management in Malaysia: Current Status and Prospects for Bioremediation (Yeoh, B G; Chee, K S; Phang, S M; Isa, Z; Idris, A and Mohamed, M eds.). Ministry of Science, Technology and the Environment, Malaysia. p. 111-136.

Madaki, Y S and Seng, L (2013). Palm oil mill effluent (POME) from Malaysia palm oil mills: Waste or resource. International J. Science Environment, 2(6): 1138-1155.

Masel, R I (1996). Principle of Adsorption and Reaction on Solid Surfaces. Vol. III, John Wiley \& Sons, University of Michigan, USA. 804 pp.

Mohammed, R R (2013). Decolourisation of biologically treated palm oil mill effluent (POME) using adsorption technique. International Refereed J. Engineering and Science, 2(10): 1-11.

Mohammed, R R and Chong, M F (2014). Treatment and decolorization of biologically treated palm oil mill effluent (POME) using banana peel as novel biosorbent. J. Environmental Management, 132: 237249.

Mohammed, R R; Ketabchi, M R and McKay, G (2014). Combined magnetic field and adsorption process for treatment of biologically treated palm oil mill effluent (POME). Chemical Engineering J., 243: 31-42.

Mohan, S V and Karthikeyan, J (1997). Removal of lignin and tannin colour from aqueous solution by adsorption onto activated charcoal. Environmental Pollution, 97(1-2): 183-187.

MPOB (2015). Malaysian Oil Palm Statistics 2014. MPOB, Bangi. 208 pp.

MPOB (2018). Number and capacities of palm oil sectors in operation as at December 2018 (tonnes/year). http:// bepi.mpob.gov.my/index. $\mathrm{php} /$ en / statistics / sectoral-status / 190-sectoralstatus-2018 / 864-number-a-capacities-of-palm-oilsectors-2018.html, accessed on 27 March 2019.
Nataraj, S K; Hosamani, K M and Aminabhavi, T M (2009). Nanofiltration and reverse osmosis thin film composite membrane module for the removal of dye and salts from the simulated mixtures. Desalinaion, 249(1): 12-17.

Neoh, C H; Yahya, A; Adnan, R; Majid, Z A and Ibrahim, Z (2013). Optimization of decolourization of palm oil mill effluent (POME) by growing cultures of Aspergillus fumigatus using response surface methodology. Environmental Science and Pollution Research, 20: 2912-2923.

Ng, W J; Goh, A C C; Tay, J H (1987). Palm oil mill effluent (POME) treatment - An assessment of coagulants used to aid liquid-solid separation. Biological Wastes, 21: 237-248.

Poh, P E and Chong, M F (2009). Development of anaerobic digestion methods for palm oil mill effluent (POME) treatment. Bioresour., 100(1): 1-9.

Poh, P E; Yong, W J and Chong, M F (2010). Palm oil mill effluent (POME) characteristic in high crop season and the applicability of high-rate anaerobic bioreactors for the treatment of POME. Industrial and Engineering Chemistry Research, 49: 11732-11740.

Ratpukdi, T (2012). Decolorization of anaerobically treated palm oil mill wastewater using combined coagulation and vacuum ultraviolet-hydrogen peroxide. International J. Chemical Engineering and Applications, 3(5): 333-336.

Rupani, P F; Singh, R P; Ibrahim, M H and Esa, N (2010). Review of current palm oil mill effluent (POME) treatment methods: Vermicomposting as a sustainable practice. World Applied Sciences J., 11(1): 70-81.

Said, M; Hasan, H A; Nor, M T M and Mohammad, A W (2016). Removal of COD, TSS and colour from palm oil mill effluent(POME) using montmorillonite. Desalination and Water Treatment, 57: 10490-10497.

Sia, Y Y; Tan, I A W and Abdullah, M O (2017). Adsorption of colour, TSS and COD from palm oil mill effluent (POME) using acid-washed coconut shell activated carbon: Kinetic and mechanism studies. MATEC Web of Conferences, 87: 1-7.

Soleimaninanadegani, M and Manshad, S (2014). Enhancement of biodegradation of palm oil mill effluents by local isolated microorganisms. International Scholarly Research Notices, 2014: 1-8.

Subramaniam, V; Ngan, MA; May, CY and Sulaiman, N M N (2008). Environmental performance of the 
milling process of Malaysian palm oil using the life cycle assessment approach. American J. Environmental Sciences, 4(4): 310-5.

Subramaniam, M N; Goh, P S; Lau, W J; Tan, Y H; $\mathrm{Ng}$, B C and Ismail, A F (2017). Hydrophilic hollow fibre PVDF ultrafiltration membrane incorporated with titanate nanotubes for decolourization of aerobically-treated palm oil mill effluent. Chemical Engineering J., 316: 101-110.

Tan, Y H; Goh, P S; Lai, G S; Lau, W J and Ismail, A F (2014). Treatment of aerobic treated palm oil mill effluent (AT-POME) by using $\mathrm{TiO}_{2}$ photocatalytic process. Jurnal Teknologi, 70(2): 61-63.

Tan, Y H; Goh, P S; Ismail, A F; Ng, B C and Lai, G S (2017). Decolourization of aerobically treated palm oil mill effluent (AT-POME) using polyvinylidene fluoride (PVDF) ultrafiltration membrane incorporated with coupled zinc-iron oxide nanoparticles. Chemical Engineering J., 308: 359-369.

Ugoji, E O (1997). Anaerobic digestion of palm oil mill effluent and its utilization as fertilizer for environmental protection. Renewable Energy, 10(2): 291-294.

Wu, T Y; Mohammad, A W; Jahim, J M and Anuar, $N$ (2010). Pollution control technologies for the treatment of palm oil mill effluent (POME) through end-of-pipe processes. J. Environmental Management, 91: 1467-1490.

Yacob, S; Hassan, M A; Shirai, Y; Wakisaka, M and Subash, S (2006). Baseline study of methane emission from anaerobic ponds of palm oil mill effluent treatment. Science of the Total Environment, 366: 187-196.
Yaser, A Z; Nurmin, B and Rosalam, S (2013). Coagulation/flocculation of anaerobically treated palm oil mill effluent (AnPOME): A review. Developments in Sustainable Chemical and Bioprocess Technology. Springer. p. 1-9.

Ying, T X (2018). Palm oil export revenue poised to hit RM80b in 2018. https:/ / www.theedgemarkets. $\mathrm{com} /$ article / palm-oil-export-revenue-poised-hitrm80b-2018, accessed on 27 March 2019.

Zahrim, A Y; Nasimah, A and Hilal, N (2014). Pollutants analysis during conventional palm oil mill effluent (POME) ponding system and decolourisation of anaerobically treated POME via calcium lactate-polyacrylamide. J. Water Process Engineering, 4: 159-165.

Zahrim, A Y; Rachel, F M; Menaka, S; Su, S Y; Melvin, $F$ and Chan, E S (2009). Decolourisation of anaerobic palm oil mill effluent via activated sludge-granular activated carbon. World Applied Sciences J., 5: 126129.

Zahrim, A Y; Tizaoui, C and Hilal, N (2010). Evaluation of several commercial synthetic polymers as flocculant aids for removal of highly concentrated C.I. acid black 210 dye. J. Hazardous Materials, 82: 624-630.

Zhang, Y J; Yan, L; Chi, L; Long, X H; Mei, Z J and Zhang, Z J (2008). Startup and operation of anaerobic EGSB reactor treating palm oil mill effluent. $J$. Environmental Science, 20: 658-663.

Zhu, X M; Nguyen, N L; Sun, B; Li, Z R and Zhan, P H (2014). Phenolic wastewater treatment. Pulsed Electrolysis with Alternative Current (Sheng, A ed.). London: Taylor \& Francis Group. p. 105-118. 